THIS IS AN EARLIER VERSION OF THE MANUSCRIPT. FOR THE FINAL VERSION, PLEASE CHECK THE JOURNAL WEBSITE: Tragant, E. and Vallbona, A. (2018). Reading while listening to learn: young EFL learners' perceptions. ELT Journal, 72(4), 395-404.

\title{
Reading while listening to learn: young EFL learners' perceptions
}

\author{
Elsa Tragant and Anna Vallbona
}

\section{$\underline{\text { Abstract }}$}

Reading while listening, that is, simultaneously reading and listening to a text, has been shown to be an efficient procedure for FL learning. It has also been considered a way of increasing the quality and quantity of L2 input as well as a form of engaging readers in the process of reading. However, little research has been conducted about this mode of reading with young, inexperienced EFL learners. The present study reports on primary students' levels of engagement and perceptions after participating on a one-year reading program at school. The results reveal that the reading-while-listening mode seems to contribute positively to the students' perceptions and level of engagement when reading in English.

\section{Introduction}

Graded readers aimed at young learners of English are a good source of materials for ELT teachers, as indicated by the inclusion of 11 series (ages 5-10) in Hill's 2013 survey. These series are generally designed for inexperienced L2 readers with very limited competence in the target language. One of the unique features of graded readers for children is that they offer three sources of input. In addition to the text (the written input), they are often accompanied by an audio file (oral input) and numerous illustrations (non-verbal input) - considerably more than in graded readers for older learners. By simultaneously reading and listening to these instructional materials, children can benefit from the advantages of both extensive reading and extensive listening. In addition, the illustrations, if effective, can help greatly in making the reading material easier, which Bamford and Day (2004) identified as an important principle of extensive reading for language learning. This paper describes a reading program in which 
students engaged with multimodal graded readers during class time over the course of an academic year.

\section{Reading while listening}

The benefits of having access to both verbal and non-verbal input is grounded on the Dual Coding Theory (Paivio 2007), which argues that these two sources of information are processed in different but complementary ways which can aid text comprehension. The benefits of having access to both written and oral input (simultaneous reading and listening) can be traced back to the development of first language literacy, where this practice has a long history, especially as a remedial approach to reading (Beers 1998). In the L2 context, reading while listening (RWL) to graded readers or short texts is not an unusual instructional practice, and recent research with teenagers and young adults has shown that it can be quite advantageous in terms of learning outcomes. It has been shown to favour the incidental acquisition of vocabulary (Webb and Chang 2012) with learners of different levels of proficiency, and also achieves greater gains in reading and listening comprehension than reading only (RO) or listening only (LO) (Chang and Millett 2014). RWL appears to be effective because it helps students to make stronger connections between form and meaning and to acquire a greater sense of the rhythm of the language. RWL may also help learners to develop word recognition and auditory discrimination skills as well as to segment text into larger meaningful chunks. Young learners of English with a low level of proficiency are likely to benefit from RWL because of their problems with text segmentation and letter-sound correspondences. Apart from improving language proficiency, engaging students in extensive reading and extensive listening programs may develop more positive attitudes towards reading in general (Renandya and Jacobs, 2016). Yet much of what we know about this instructional practice comes from research with adults and teenagers, rather than children. 
Empirical research with children on the effectiveness of extended reading is also scarce and much of it comes from the book flood studies that were conducted in the eighties (Elley 1991). Among the clearest findings from those studies are the positive attitudes towards books that children developed. Positive attitudes also emerged in a major experimental reading program (Lightbown 1992) in Canada that involved children (aged 8-10) engaged in RWL for daily periods of half an hour. Results from parent questionnaires and student interviews showed that they enjoyed the program and that those who had been in the program for three years still felt enthusiastic about it. Similarly positive attitudes were found in a recent smallscale reading program in Spain (Tragant, Muñoz and Spada 2016) that took place over the course of one academic year. In that program, the group of students (aged 10-11) who participated in the RWL sessions had more favourable attitudes towards learning English than those in a comparison group who learned English exclusively through teacher-led instruction. In both the programs in Canada and Spain, learners had access to a class library that included a variety of materials (including fiction and non-fiction, graded readers and story books) of different levels of difficulty that they could choose from.

Given the interest that extensive reading and RWL seem to arouse among young language learners, further examination of how they engage with the texts they are exposed to seems well justified. It will also be of interest to compare students' attitudes towards RWL and RO. Older students have been shown to prefer the RWL mode (Brown, Waring and Donkaewbua 2008) but we are not aware of any study that has made this comparison with children.

The study

A reading program was implemented during 2015-2016 with upper primary school children who were learning English as a foreign language in Barcelona (Spain). The program started in October and finished in May, and it involved reading extensively in a semi-autonomous way 
with the supervision of their English teacher. The motivation behind the program was to maximize the quantity and quality of input these children would be exposed to via the use of age-appropriate graded readers.

In this paper we will discuss how students engaged with the reading materials and how they perceived the experience. In doing so, we will also compare students in a RWL group ( $n=48$ ) with students in a RO group ( $n=22)$, drawing on interviews (17 in the RWL group and six in the RO group) as well as questionnaires and classroom observations. Information about the linguistic gains of the reading program can be found in Llanes, Tragant, Pinyana and Cerviño (2016) and Serrano, Andriá and Pellicer-Sánchez (2016).

\section{The reading program}

The study was conducted with two groups of 10-11 year old students (grade 5) from a semiprivate school located outside the city center of Barcelona. Students spent two of their class periods ( $2 \mathrm{~h} /$ week) engaged with graded readers. One of these groups (two classes of 24 and 25 students each) was exposed to RWL and the other to RO (a class of 24 students). The same reading materials were used with the two groups, a selection of 39 non-fiction graded readers, which all students were required to read. The books were chosen from four non-fiction collections ('Oxford Read and Discover', Benchmark Education 'English Explorers', 'Macmillan Children's Readers' and 'Macmillan Science Readers') on topics related to the science curriculum (Elephants, Minibeasts, Volcanoes, Life in the Forest, Ancient Egypt, Why we recycle, etc.), a subject which is partially delivered through English in this school. Books ranged from 15 to 31 pages long and had large photographs and illustrations on each page. The graded readers from the 'Macmillan Children's Readers' included two parts on the same topic, one non-fiction and the other fiction. The difficulty of books increased slightly throughout the school year. From October to February most of the graded readers aimed at grades 3-4 (with an average of 908 words per book) and from March till May, most of them aimed at grades 4-5 
(with an average of 1615 words per book). The reading speed of the audio files ranged from 76 to 123 words per minute, depending on the book collection and level.

In class, students were supposed to spend approximately 20 minutes per session engaged with reading/listening. When the books took less than ten minutes to read, students were asked to read them twice; if the reading lasted longer, students were asked to reread them partially. On finishing reading/listening to the book, students were asked to perform two written post-reading activities. One of these activities consisted in selecting eight 'new' words and translating them, and the other involved language production. From October to February, students were asked to write questions (Wh-, True/False, Multiple choice) about the content of the book they had just read which would later be used to run a class contest. If there was time left, they were encouraged to ask a classmate their questions. From February till May, the language production task changed; students were now asked to answer a set of about 20 whand true/false questions about the book and not read the book a second time. The change in the format of the language production task was due to the fact that the task of creating the questions proved to be too challenging for some of the learners. During all the sessions students had bilingual dictionaries available to them and those doing RWL had a set of headphones and an MP3 to be able to listen individually to the books.

\section{$\underline{\text { Results }}$}

General evaluation: motivating factors

The results of the questionnaires distributed at the end of this one-year project indicate an overall positive reaction (see question 1 in Appendix 1) especially from the students in the RWL group $(M=3.23, S D=.95)$, which showed significantly better attitudes than the RO group $(M=2.73, S D=1.03)$ (see Appendix 2). In fact, twice as many students in the RWL (62.5\%) than in the RO group (31.8\%) stated that they would consider repeating the experience the following year (see question 2 in Appendix 1). These findings were further substantiated in the student 
interviews in which students in the RWL reported liking the idea of reading, but especially the idea of reading and listening at the same time. They mentioned the fact that reading with audio books was 'fun', 'cool', 'different' and 'not normal'. In the words of a learner (21RWL), 'instead of work, we are sort of reading books, well not reading, listening to something similar to books'. Students seemed to associate 'the headphones method', as one student put it, with a type of leisure situation that was not only enjoyable (it did not require them to write or use coursebooks or workbooks) but different from what they associated with an English lesson. Some students from both the RWL and the RO groups also mentioned a range of other positive aspects in connection with the sessions, like 'learning things they did not know', liking the session because they were keen on reading, having a feeling of learning English, or liking the fact that they were working on their own.

General evaluation: Demotivating aspects

Some of students (from both groups) also mentioned demotivating aspects, such as not liking reading in English, finding the sessions repetitive, losing interest as the school year went by, losing interest on the second reading ('because you already know the book' 8RWL), or not having enough time (to complete the post-reading activities). Four students from the RO group did not like the fact that the sessions took place after the break or in the late afternoon. Two students, with a low and a high level of English respectively, showed a preference for reading the graded readers with the teacher. The first reported finding it very difficult to look up words in the dictionary, while the second thought that 'we would know more (with the help of the teacher) and learning would be easier' 4RWL.

The reading process

Most students in the two groups actually reported reading the books without skipping pages or just skimming them (see question 8 Appendix 1). Students' level of attention while reading (see question 3 in Appendix 1) tended to be higher in the RWL group $(M=2.27, S D=.74)$ than in 
the $R O$ group ( $M=1.86, S D=1.04$ ) and the difference almost reached significance (see Appendix 2). During the classroom observations, students in the RWL group were also seen to be more focused while reading. The use of electronic devices probably gave students in the RWL group more of a feeling of working quietly in a way they were not used to in their regular English classes. One student said: 'You are concentrated because you don't hear anything. You kind of feel better, more at peace while you write and so on' (4RWL). The listening element had a strong influence on how most RWL students reported processing the text (see question 9 Appendix 1): $47.8 \%$ said they paid the same attention to both listening and reading and $37 \%$ paid more attention to listening. A couple of students during the interviews referred to what they were doing in the sessions as 'listening', not reading ('I like the fact that we do not need to read' $23 \mathrm{RWL}$ ) and that they were spending more time listening during the sessions than in the normal English classes, in which 'you just need to open the book and you don't do any listening, just the teacher speaking' (23RWL). Another student also said that if it had not been for the audio support she would not have liked the sessions since she did not like reading.

Post-reading activities

Students' level of motivation towards the post-reading activities (see question 4 Appendix 1 ) was lower than their general evaluation of the sessions (see question 1), especially in the case of the RWL group, and there were no differences between the RWL $(M=1.7, S D=0.92)$ and RO groups $(M=1.55, S D=1.01$ ) (Appendix 2). Some students were observed to use avoidance strategies to complete these activities such as copying words that they already knew in the vocabulary list or copying full sentences when they were supposed to write their own questions.

The lower level of motivation with regard to post-reading activities may be in part due to the fact that these were pencil and paper activities and, therefore, quite similar to the ones students were used to doing in their English classes. Also, during the interviews, some students 
reported having difficulty in using dictionaries when completing the post-reading activities and noted occasional frustration at not finding some words (e.g., 'deepest', 'Vesuvius'). On the other hand, some students had difficulty in finding 'new words' because they found some of the books easy. Finally, some students felt that there were too many comprehension questions and mentioned that they often ran out of time before being able to finish them.

The graded readers

When the students in both groups were asked about the level of difficulty of the graded readers (see question 7 Appendix 1), more than two thirds described the level as 'fine' in the questionnaire and the responses in the two groups were similar (RWL, $M=2.1 S D=0.5 ; \mathrm{RO}$ $M=2.09 S D=.54)$. Two students valued the fact that, in spite of the difficulties they experienced when reading, they still managed to understand the books.

Students tended to use positive adjectives such as 'interesting', 'fun' and 'entertaining' to refer to the graded readers and, even though they were not specifically asked about the pictures, one student commented: 'the photographs are beautiful and sometimes they are very strange and spectacular' (3RWL). In general, they reported having learned new information from them. However, for some students the question of how much they liked a book depended on the topic, their familiarity with the topic (so that they could learn more), or the format of the book (two students had a preference for the graded readers that included a section on fiction). Two students found the audio of some books too slow and one of them felt the books were too short. All these factors go to explain why the evaluation of the books in the questionnaire was diverse (see question 6 Appendix 1 ) and similar in the two groups (RWL, $M=2.77 S D=0.86 ;$ RO $M=2.67 S D=1.01$ ). While approximately 2 out of every 10 students in both groups liked the books 'a lot', around 4 and 3 out of 10 (in the RWL and RO respectively) said they did 'not' like them 'much' or just 'a little'.

Reading to learn about the world 
Students in the interviews seem to have really focused their attention on making meaning out of the non-fiction books. One student reported feeling keen to find out which book they would read at the beginning of each session. When asked what they had learned after a given reading session, students often responded 'things that I did not know' or 'new things' and were seen to make connections with their prior knowledge. Most of them could also successfully explain some of what they had learnt. For example, one student (4RWL) said about a graded reader titled 'Volcanoes':

I have learned that there is a volcano that started to erupt in 1939 and is still erupting. And that there is another volcano that is higher than the Everest....And also that there are more volcanoes under water than on the ground.

Another student (2RWL) contrasted what he knew about horses with the information he learned from a graded reader: 'I have learned there were horses in prehistoric times. I thought that horses came into existence with the Trojans'. When specifically asked about the English they had learned from reading the books, the response from a couple of children was still about the content of the books.

Two children spontaneously compared the information they had gained from reading the books with their English lessons to say that they were learning more from the reading sessions. One student compared the graded readers with their science textbook in Catalan and said the latter did not include as much information on a given topic. However, two students stated that they had not learned much content from certain books because they had previously covered the topic at school. One student mentioned that she would prefer having more text and fewer pictures 'to be able to learn more new things' (4RWL).

Learning English from reading 
When the participants were asked about how much they had learnt in terms of English (see question 5 Appendix 1), the mean responses of the two groups were similar ( $R W L, M=2.78 S D=$ 0.85; RO $M=2.67 S D=0.86$ ) and the differences were not significant. About seven out of ten students in the two groups felt they had learned 'some' or 'a little' English; however, the proportion of students who felt they had learned 'a lot' was higher in the RWL group (22\%) than in the RO group (14\%) and those who felt they had 'not' learnt 'much' was lower in the RWL group (4\%) than in the RO group (9\%).

In the interviews, the majority of the students (16 out of 20$)$ mentioned having learnt about the meaning and/or pronunciation of words: 'When I started I didn't know how to pronounce many of the words, but now, as I have read them and I have listened to them, I know how to pronounce them' (21RWL). One student attributed the improvement in pronunciation to 'hearing words directly, the way a person says them' (4RWL). There were also nine students who also mentioned improving in reading or in their ability to make sentences. After a reading session two students (one lower level and one higher level) reported not having learned as much English as they could have learnt, but for two very different reasons. The lower level student attributed it to having to concentrate on reading, which she found difficult, and not being able to pay attention to the language, whereas the higher level student attributed it to knowing most of the words in the books. In both cases, however, the two students reported 'learning things' from their books.

\section{$\underline{\text { Discussion and conclusions }}$}

The reading sessions in this study fulfilled some of the principles for an extensive reading program (Day and Bamford 2002) though not all of them (no choice of books, only non-fiction titles, availability of dictionaries, post-reading activities). Yet most students seemed to enjoy the reading experience - especially those engaged in the RWL mode, for whom the listening component was particularly important. The popularity of RWL in this study corroborates 
reports with similar RWL programs with children (Lightbown et al. 1992; Tragant et al. 2016.) It seems that the dual input mode of RWL makes the experience attractive to a high number of young language learners, including those who are not keen on reading.

According to Macalister (2014), some teachers equate extensive reading with reading fiction. However, this assumption is challenged in this study in which non-fiction graded readers were successful in engaging students to read and learn about the world and at the same time enjoy the experience. Thus, a combination of fiction and non-fiction readers seems to be highly appropriate for young learners' extensive reading programs.

The decision to have all students read the same books without giving them any choice was motivated by the research aims (i.e., the wish to keep track of their vocabulary learning). However, the fact that some students did not have a higher perception of learning English is probably in part due to this lack of choice. If students had been able to choose, they would have had the opportunity to read books that matched their own level of proficiency and they would have probably got more out of them. The ability to choose would also have saved students from reading books they were not interested in, felt they knew enough about, regarded as too short, and so on.

In sum, this study has shown that young language learners clearly prefer reading graded readers with audio support to just reading alone, and that doing so independently through an electronic device gives them a sense of autonomy that they love. This project has shown that this age group can enjoy non-fiction as much as fiction graded readers. It has also provided evidence of the drawbacks of not allowing students to choose their books, and suggests that allowing them this choice should be an element of future extensive reading programs for young learners. 


\section{$\underline{\text { References }}$}

Bamford, J. and R. Day. (eds.) 2004. Extensive reading activities for teaching language. Cambridge: CUP.

Beers. K. 1998. 'Listen while you read'. School Library Journal April: 30-45.

Brown, R., R. Waring and S. Donkaewbua. 2008. 'Incidental vocabulary acquisition from reading, reading-while-listening, and listening to stories'. Reading in a Foreign Language 20/2: 136-163.

Chang, A. and S. Millett. 2014. The effect of extensive listening on developing L2 listening fluency: Some hard evidence. ELT Journal 68/1: 31-40.

Day, R. and J. Bamford. 2002. 'Top ten principles for teaching extensive reading'. Reading in a Foreign Language 14/2, 136-141.

Elley, W. 1991. 'Acquiring literacy in a second language: The effect of book-based programs'. Language Learning 41/3: 375-411.

Hill, D. R. 2013. Survey review: 'Graded readers'. ELT Journal 67/1: 85-125.

Lightbown, P.M. 1992. 'Can they do it themselves? A comprehension-based ESL course for young children' in R. Courchene, J. St John and C. Therrien, J. Glidden, (eds.). Comprehension-based Second Language Teaching. Ottawa: University of Ottawa Press.

Llanes, À., E. Tragant, A. Pinyana and E. Cerviño. 2016 November. The impact of reading modality on reading fluency and comprehension in English as a foreign language: the case of children. Paper presented at the 'Multimodal input in second language learning' Symposium, Barcelona, Spain.

Macalister, J. 2014.' Teaching reading: Research into practice'. Language Teaching 47/3: 387397. 
Paivio, A. 2007. Mind and its evolution: A dual coding theoretical approach. Mahwah, NJ: Erlbaum.

Renandya, W.A. and G. M. Jacobs. 2016. 'Extensive reading and listening in the language classroom' In W.A. Renandya and H.P. Widodo, (eds.). English Language Teaching Today: Linking Theory and Practice. Switzerland: Springer International Publishing.

Serrano R., M. Andriá and A. Pellicer-Sánchez. 2016 November. Reading-while-listening in primary school: Linguistic and non-linguistic outcomes. Paper presented at the 'Multimodal input in second language learning' Symposium, Barcelona, Spain.

Tragant E., C. Muñoz and N. Spada. 2016. 'Maximizing young learners' input: An intervention program'. The Canadian Modern Language Review 72/2: 234-257.

Webb, S. and A. Chang. 2012. 'Vocabulary learning through assisted and unassisted repeated reading’. Canadian Modern Language Journal 68/3: 267-290.

\section{The authors}

Elsa Tragant is an associate professor of Applied Linguistics at the University of Barcelona. Her research interests include: reading while listening and extensive reading in young learners, language learning motivation and classroom research.

\section{Email : tragant@ub.edu}

Anna Vallbona is the Primary degree coordinator of the Faculty of Education, Human sciences and Translation at the University of Vic. Her research interests include extensive reading and CLIL with young learners.

Email: anna.vallbona@uvic.cat 
Appendix 1: Descriptive results from questionnaire (percentages and frequencies)

Motivation towards the sessions

1 Did you like the reading/(listening to) sessions in English?

\begin{tabular}{lcc}
\hline & $\begin{array}{c}R W L \text { group } \\
n=48\end{array}$ & $\begin{array}{c}\text { RO group } \\
n=22\end{array}$ \\
\hline Not much & $8.3 \%(4)$ & $13.6 \%(3)$ \\
A little bit & $10.4 \%(5)$ & $27.3 \%(6)$ \\
Quite & $31.3 \%(15)$ & $31.8 \%(7)$ \\
A lot & $50 \%(24)$ & $27.3 \%(6)$ \\
\hline
\end{tabular}

2 If you were given the option of continuing with these sessions next year, would you want to?

\begin{tabular}{lcc}
\hline & RWL group & RO group \\
& $n=48$ & $n=22$ \\
\hline Don't know & $29.2 \%(14)$ & $36.4 \%(8)$ \\
No & $8.3 \%(4)$ & $31.8 \%(7)$ \\
Yes & $62.5 \%(30)$ & $31.8 \%(7)$ \\
\hline
\end{tabular}

Level of engagement during reading/(listening) sessions

3 Did you read/ (listen to) attentively?

\begin{tabular}{lll}
\hline & \multicolumn{1}{c}{$\begin{array}{c}\text { RWL group } \\
n=48\end{array}$} & $\begin{array}{c}\text { RO group } \\
n=22\end{array}$ \\
\hline Not much & $2.1 \%(1)$ & $13.6 \%(3)$ \\
A little bit & $10.4 \%(5)$ & $18.2 \%(4)$ \\
Quite & $45.8 \%(22)$ & $36.4 \%(8)$ \\
A lot & $41.7 \%(20)$ & $31.8 \%(7)$ \\
\hline
\end{tabular}

4 How motivated were you to do the activities?

\begin{tabular}{lll}
\hline & $\begin{array}{c}\text { RWL group } \\
n=48\end{array}$ & $\begin{array}{c}\text { RO group } \\
n=22\end{array}$ \\
\hline Not much & $10.4 \%(5)$ & $18.2 \%(4)$ \\
A little bit & $29.2 \%(14)$ & $27,3 \%(6)$ \\
Quite & $39.6 \%(19)$ & $36.4 \%(8)$ \\
A lot & $20.8 \%(10)$ & $18.2 \%(4)$ \\
\hline
\end{tabular}

Perceived amount of learning
5 How much have the reading/(listening) sessions helped you learn English?

\begin{tabular}{lll}
\hline & $\begin{array}{c}\text { RWL group } \\
n=48\end{array}$ & $\begin{array}{c}\text { RO group } \\
n=22\end{array}$ \\
\hline Don't know & $6.3 \%(3)$ & $4.5 \%(1)$ \\
Not much & $4.2 \%(2)$ & $9.1 \%(2)$ \\
A little bit & $33.3 \%(16)$ & $27.3 \%(6)$ \\
Quite & $35.4 \%(17)$ & $45.5 \%(10)$ \\
A lot & $20.8 \%(10)$ & $13.6 \%(3)$ \\
\hline
\end{tabular}

Evaluation of the graded readers

6 In general, did you like the books?

\begin{tabular}{lll}
\hline & $\begin{array}{c}\text { RWL group } \\
n=48\end{array}$ & $\begin{array}{c}\text { RO group } \\
n=22\end{array}$ \\
\hline Don't know & & $4.5 \%(1)$ \\
\hline Not much & $6.3 \%(3)$ & $18.2 \%(4)$ \\
\hline A little bit & $31.3 \%(15)$ & $13,6 \%(3)$ \\
\hline Quite & $41.7 \%(20)$ & $45.5 \%(10)$ \\
\hline A lot & $20.8 \%(10)$ & $18.2 \%(4)$ \\
\hline
\end{tabular}

7 In general, what do you think about the level of difficulty of the books?

\begin{tabular}{lll}
\hline & $\begin{array}{c}R W L \text { group } \\
n=48\end{array}$ & $\begin{array}{c}\text { RO group } \\
n=22\end{array}$ \\
\hline Don't know & $6.3 \%(3)$ & $4.5 \%(1)$ \\
Too difficult & $6.3 \%(3)$ & $9.1 \%(2)$ \\
Fine & $68.8 \%(33)$ & $68.2 \%(15)$ \\
Too easy & $18.8 \%(9)$ & $18.2 \%(4)$ \\
\hline
\end{tabular}

\section{About the reading(/listening) process}

8 How did you usually read/(listen to) the books?

\begin{tabular}{|c|c|c|}
\hline & $\begin{array}{c}R W L \text { group } \\
n=48\end{array}$ & $\begin{array}{c}R O \text { group } \\
n=22\end{array}$ \\
\hline I read all the pages & $89.6 \%(43)$ & $81.8 \%(18)$ \\
\hline I read some pages & $6.3 \%(3)$ & $13.6 \%(3)$ \\
\hline I skimmed the text & $4.2 \%(2)$ & $4.5 \%(1)$ \\
\hline
\end{tabular}

9 What did you pay more attention to? (addressed to RWL group) 


\begin{tabular}{ll}
\hline To what you listened to & $37 \%(17)$ \\
To what you read & $15.2 \%(7)$ \\
To both to the same extent & $47.8 \%(22)$ \\
\hline
\end{tabular}

10 What did you pay more attention to?

(addressed to RO group)

\begin{tabular}{ll}
\hline & \multicolumn{1}{c}{$\begin{array}{c}R O \text { group } \\
N=22\end{array}$} \\
\hline To the images & $13.6 \%(3)$ \\
\hline To the text & $22.7 \%(5)$ \\
\hline To both to the same extent & $63.6 \%(14)$ \\
\hline
\end{tabular}


Appendix 2. Comparison of mean scores in questionnaire questions

\begin{tabular}{|c|c|c|c|c|c|}
\hline & $\begin{array}{c}\text { RWL group } \\
\mathrm{N}=48 \\
M(S D)\end{array}$ & $\begin{array}{c}\text { RO group } \\
\mathrm{N}=22 \\
M(S D)\end{array}$ & $t$ & $d f$ & sig. \\
\hline $\begin{array}{l}\text { Did you like the reading/(listening to) } \\
\text { sessions in English? }\end{array}$ & $3.23(.95)$ & $2.73(1.03)$ & 2 & 68 & .05 \\
\hline Did you read/(listen to) attentively? & $2.27(.74)$ & $1.86(1.04)$ & 1.88 & 68 & .06 \\
\hline $\begin{array}{l}\text { How motivated were you to do the } \\
\text { activities? }\end{array}$ & $1.71(.92)$ & $1.55(1.01)$ & .67 & 68 & ns \\
\hline $\begin{array}{l}\text { How much have the reading/(listening) } \\
\text { sessions helped you learn English? }\end{array}$ & $2.78(.85)$ & $2.67(0.86)$ & .49 & 64 & ns \\
\hline In general, did you like the books? & $2.77(.86)$ & $2.67(1.01)$ & .44 & 67 & ns \\
\hline $\begin{array}{l}\text { In general, what do you think about the } \\
\text { level of difficulty of the books? }\end{array}$ & $2.1(.50)$ & $2.09(.54)$ & .28 & 64 & ns \\
\hline
\end{tabular}

[text + appendices (without references) 4.003 words] 